\title{
Eco-friendly Management of Anthracnose of Chilli (Capsicum annuum L.) caused by Colletotrichum capsici (Syd.) Butler and Bisby
}

\author{
Rohan D. Lokhande*, Shashi Tiwari and Rupesh V. Patil
}

Department of Plant Pathology, Sam Higginbottom University of Agriculture, Technology and Sciences, Allahabad-211007 U. P., India

*Corresponding author

\begin{tabular}{|c|c|}
\hline & A B S T R A C T \\
\hline Keywords & \multirow{4}{*}{$\begin{array}{l}\text { A field experiment was conducted to evaluate the effect of bioagents and botanicals in vivo } \\
\text { during kharif, } 2017 \text { to manage anthracnose caused by Colletotrichum capsici on chilli } \\
\text { (Capsicum annuum L.).The anthracnose of chilli is one of the most devastating diseases. } \\
\text { The various factors viz. nutritional, physical and toxicological factor showed wide } \\
\text { variation on growth and sporulation of } C \text {. capsici. The effect of treatments on anthracnose } \\
\text { disease management of chilli in field condition revealed that all the treatments showed } \\
\text { significant reduction in the intensity and over control. Average disease intensity and its } \\
\text { average reduction over control recorded with all the treatments were ranged from } 19.84 \text { to } \\
31.18 \text { per cent and } 52.97 \text { to } 26.09 \text { per cent, respectively. Antagonistic ability of } \\
\text { Trichoderma viride and Pseudomonas fluorescens was tested by dual culture test against } \\
\text { pathogen. Among them Trichoderma viride was found effective in inhibiting the growth of } \\
\text { C. capsici. The toxicological factors like Eucalyptus oil, Neem oil and Garlic bulb extract } \\
\text { were found effective. }\end{array}$} \\
\hline & \\
\hline Article Info & \\
\hline & \\
\hline
\end{tabular}

\section{Introduction}

Chilli (Capsicum annuum L.) is an important vegetable as well as spice crop, cultivated worldwide. It is not only used in many cuisines but also found to have many medicinal properties. The genus Capsicum comprises about 20-25 species, out of which $C$. annuum, $C$, baccatum, $C$. chinense, $C$. frutescens and $C$. pubescens are cultivated. Capsicum annuum is widely cultivated variety, second being $C$. frutescens. Commonly used term is Chilli, which refers to hot types of Capsicum. Though it was originated in the American tropics, it is widely propagated (Sahitya et al., 2014).

Chilli is an important commercial crop grown in India. India emerged as leading producer and exporter of chilli contributing one fourth of world's production. The strong spicy taste comes due to the presence of active alkaloid compounds capsaicin, capsanthin, capsorubin. Chilli contains steam volatile oils, carotenoids, fatty oils, vitamins, mineral elements etc. Chilli is an important commercial crop grown in India. Andhra Pradesh, Orissa, Maharashtra, West Bengal, 
Uttar Pradesh, Karnataka, Rajasthan and Tamil Nadu are found to be important states growing chilli in India (Sahitya et al., 2014).

Chilli anthracnose was first reported in India on from the Coimbatore of Madras Presidency (Sydow, 1913). The disease has been identified in all the chilli producing regions of the world and has become a serious constraint to chilli production. Different species of Colletotrichum, namely C. capsici, C. gloeosporioides, $C$. acutatum are known to cause anthracnose in chilli in India. Anthracnose disease appears as small circular spots that coalesce to form large elliptical spots on fruits and leaves. Under severe conditions, defoliation of affected plants occurs.

Among all the diseases, anthracnose disease is the major constraint to chilli production worldwide resulting in high yield losses. This fungal disease caused by Colletotrichum species drastically reduces the quality and yield of fruit resulting in low returns to farmers. $10-80 \%$ of marketable yield is reduced in Thailand, about $13 \%$ in Korea. This die back/ fruit rot/ anthracnose disease is seen on mature fruits resulting in both pre harvest and post-harvest fruit loss. In India, in severe cases, pre harvest and post-harvest losses comprise up more than $50 \%$. Significant yield losses were reported from Punjab and Haryana (20-60\%) and Assam (12-30\%) (Sahitya et al., 2014). Among the fungal diseases, anthracnose caused by Colletotrichum spp. is considered to be the major constrain to increase chilli production. It occurs every year with varying intensities and inflicts considerable quantitative and qualitative losses of the crop in the fields as well as in the storage. Anthracnose is mainly a problem on mature leaves and fruits, causing severe losses due to both pre-harvest and post-harvest fruit decay (Hadden and Black, 1989; Bosland and Votava, 2003). Four species of Colletotrichum; C. capsici, $C$. gloeosporioides, $C$. acutatum and $C$. coccodes have been reported as causal agents of pepper anthracnose in many countries. The major species are $C$. capsici and $C$. gloeosporioides (Hadden and Black, 1987).

For the management of anthracnose of Chilli, now a day's increasing use of chemical has challenged both public health and environment hazards. Thus emphasis for using botanicals such as plant extract and bioagents for the management of the plant disease which is less costly and environment friendly.

\section{Materials and Methods}

The experiment was conducted in the research laboratory of Department of Plant Pathology and Central Research Farm, Sam Higginbottom University of Agriculture, Technology and Sciences, Allahabad. The experiment was laid out Randomized Block Design with three replications and Eight Treatments. Three spraying of all the treatments were undertaken at 15 days interval, starting first spray at appearance of anthracnose symptoms. One plot per replication was maintained as the control. Five plants per treatment per replication were selected randomly and tagged; three leaves (bottom, middle and top) from main branch on each observation plant were selected for recording observations. Observations on foliage anthracnose disease intensity were recorded applying standard 0-9 grade disease rating scale (Mayee and Datar, 1986) one day before each spraying and last observation was recorded.

\section{Standard disease rating scale (0-9 scale) for assessing PDI of anthracnose of chilli}

0-No symptoms on plant.; 1- Small spots on leaves, less than 1 per cent of leaf area diseased; 3- Medium six spots on leaves covering 1-10 per cent infected area; 5- Spots 
big; coalescing covering 11-25 per cent of leaf area.; 7- Spots large; coalescing covering 26-50 per cent of leaf area; 9- Spots on leaves covering above 51 per cent of leaf area.

\section{Collection, Isolation and purification}

The anthracnose disease samples (just after initiation of the disease) were collected in polythene bags from various plants from research plot of the Department of Plant Pathology, Sam Higginbottom University of Agriculture, Technology and Sciences, Allahabad (U.P.). The chilli leaves exhibiting disease symptoms were brought to the laboratory for isolation. The anthracnose infected parts were cut into small pieces by sterilized stainless steel blade and surface sterilized with $0.1 \%$ mercuric chloride for one minute followed by three washing with sterilized water. Anthracnose infected pieces were placed in petriplates containing $20 \mathrm{ml}$ of solidified potato dextrose agar (PDA) medium mixed with streptomycin sulphate to avoid bacterial contamination. Plates were kept for incubation at $28 \pm 2{ }^{\circ} \mathrm{C}$ in an incubator. Fungal colonies appeared within 5-7 days, they were sub cultured in PDA slants and purified.

\section{Efficacy of bioagents on the radial growth of $C$. capsici in vitro}

Pseudomonas fluorescens: P. fluorescens were tested for their antagonistic ability against $C$. capsici by dual culture method on PDA medium and allowed to solidify. $5 \mathrm{~mm}$ mycelial disc were cut from young growing edge of the fungus from seven days old culture and placed at one side of petriplates. The Pseudomonas fluorescens whose inhibition ability need to be tested were streak parallel to the fungus roughly at a distance of $15-20 \mathrm{~mm}$ and incubated at $28 \pm 2^{\circ} \mathrm{C}$ for seven days and percentage of inhibition of the fungus was calculated.

\section{Trichoderma viride}

The Trichoderma viride were screened for their antagonistic ability by dual culture method on PDA medium. An amount of 20 $\mathrm{ml}$ PDA was poured in $90 \mathrm{~mm}$ sterilized petriplates. A $5 \mathrm{~mm}$ disc of $C$. capsici was taken from the margin of young vigoursly growing culture and placed at the one end in petriplates and at the other end, four days old pure culture of the Trichoderma viride were inoculated roughly at a distance of $15-20 \mathrm{~mm}$ and placed in incubator at $28 \pm 2^{\circ} \mathrm{C}$. Three replications for each treatment were maintained. The observations of per cent zone inhibition between the antagonists and test fungus were recorded after 7 days of incubation period and the per cent growth inhibition was calculated.

Per cent inhibition of colony $=\frac{C-T}{C} \times 100$ (Dennis and Webster, 1971).

Where, $\mathrm{C}=$ Colony diameter in control

$\mathrm{T}=$ Colony diameter in treatment

\section{Effect of different botanicals against $C$. capsici in vitro}

To test the antifungal activity of some botanicals was studied in vitro by poisoned food technique (Nene and Thapliyal, 1971). Different Botanicals named as Neem oil, Eucalyaptus oil, Garlic Bulb, Tulsi, Datura were used. The plant materials (100 gm) were blended with $100 \mathrm{ml}$ water till they become soften and pulpy, then extract was filtered. After that each plant extracts were dispensed in $100 \mathrm{ml}$ melted PDA in conical flasks, separately (garlic bulb extract, Tulsi leaves extract, Datura leaf extract, neem oil and Eucalyptus oil each@5\%). Trace amount of streptomycin sulphate was added to prevent bacterial contamination and then poured into $90 \mathrm{~mm}$ petriplates. 
The plain PDA plates served as control. A 5 $\mathrm{mm}$ disc of seven days old culture of fungus was placed on the center of the medium and kept in incubator at $28 \pm 2^{\circ} \mathrm{C}$.

Three replications were maintained for each treatment and observations of radial growth were recorded after second day at regular interval of two days up to 7 days. The observations recorded at 7 th day were used for computation.

\section{Results and Discussion}

\section{Efficacy of Bioagents and Botanicals against $C$. capsici in vitro}

Studies on antagonistic ability tested, exhibited significant mycelial growth inhibition of $C$. capsici. However, it was significantly highest with Trichoderma viride (74.22\%), followed by Pseudomonas fluorescens $(57.56 \%)$.

Results (Table 1) revealed that the Eucalyptus oil was found most effective with least mycelial growth $(0.00 \mathrm{~mm})$ and significantly highest mycelial inhibition $(100 \%)$ of the test pathogen. All the plant extract showed their inhibitory influence on the growth of $C$. capsici.

The radial growth of $C$. capsici was minimum in Garlic Bulb extract, Datura leaf extract and Tulsi leaves extract as compared to control. Thus all the extracts of plants of different species adversely affect the growth of $C$. capsici. The inhibitory effect of volatile oil of Eucalyptus on mycelial growth and sporulation of $C$. capsici was also reported by Ramezani et al., (2002), which supports the present findings. Bioagents viz., T. viride and $P$. fluorescens were reported as efficient antagonists against many Colletotrichum spp by several earlier workers (Tiwari et al., 2008; Pardhi and Raut, 2011).

\section{Disease intensity}

The results (Table 2) of the effect of treatments on anthracnose disease management of chilli in field condition revealed that all the treatments showed significant reduction in the intensity and over untreated control during kharif, 2017. After first spraying, the disease intensity ranged from 14.66 (Trichoderma viride) to 26.87 (Datura leaf extract) as against 27.26 per cent in the unsprayed control, and all the treatments were found significantly superior over unsprayed control. After second spraying, the disease intensity recorded was comparatively over that of observed after first spraying and was ranged from 20.26 (Trichoderma viride) to 30.14 (Tulsi Leaves extract) as against 32.79 per cent in unsprayed control, and all the treatments were found significantly superior over unsprayed control. After Third spraying, the disease intensity recorded ranged from 24.60 (Trichoderma viride) to 38.14(Datura leaf extract) as against 68.53 percent in unsprayed control, and all the treatments were found significantly superior over unsprayed control.

Average disease intensity and its average reduction over unsprayed control with all the spray treatments were ranged from 19.84 (Trichoderma viride) to 31.18 (Datura leaf extract) per cent and 26.09 (Datura leaf extract) to 52.97 (Trichoderma viride) per cent, respectively.

The Trichoderma viride as a bioagent and Garlic Bulb Extract as a botanical could also effectively manage anthracnose of chilli (Kamble et al., 2015). The phytoextracts viz., Garlic bulb, Tulsi leaves extract were reported antifungal fungistatic against many Colletotrichum spp, earlier by several workers (Jayalakshmi et al., 1998; Shinde and Gawai, 2014) (Fig. 1-3). 
Table.1 Efficacy of bioagents and botanicals against $C$. capsici in vitro

\begin{tabular}{|c|l|c|c|}
\hline $\begin{array}{c}\text { Tr. } \\
\text { No. }\end{array}$ & \multicolumn{1}{|c|}{ Treatments } & $\begin{array}{c}\text { Radial growth of } \\
\text { pathogen }(\mathbf{m m})\end{array}$ & $\begin{array}{c}\text { Percent } \\
\text { Growth } \\
\text { inhibition }\end{array}$ \\
\hline $\mathbf{T}_{\mathbf{0}}$ & Control & 75 & 0.00 \\
\hline $\mathbf{T}_{\mathbf{1}}$ & Trichoderma viride & 19.33 & 74.22 \\
\hline $\mathbf{T}_{\mathbf{2}}$ & Pseudomonas fluorescens & 31.83 & 57.56 \\
\hline $\mathbf{T}_{\mathbf{3}}$ & Garlic bulb extract & 33.66 & 55.12 \\
\hline $\mathbf{T}_{\mathbf{4}}$ & Datura leaf extract & 36.66 & 51.12 \\
\hline $\mathbf{T}_{\mathbf{5}}$ & Neem oil & 29.00 & 61.33 \\
\hline $\mathbf{T}_{\mathbf{6}}$ & Tulsi leaves extract & 40.00 & 46.66 \\
\hline $\mathbf{T}_{\mathbf{7}}$ & Eucalyptus oil & 0.00 & 100 \\
\hline & F- test & $\mathbf{S}$ & - \\
\hline & S.E. \pm & $\mathbf{0 . 5 2}$ & - \\
\hline & C.D. $(\mathbf{P}=\mathbf{0 . 0 5})$ & $\mathbf{1 . 1 1}$ & - \\
\hline
\end{tabular}

Table.2 Efficacy of various treatments against anthracnose disease intensity in vivo condition

\begin{tabular}{|c|c|c|c|c|c|c|c|}
\hline \multirow[t]{2}{*}{$\begin{array}{l}\text { TR } \\
\text { No. }\end{array}$} & \multirow[t]{2}{*}{ Treatments } & \multirow{2}{*}{$\begin{array}{c}\text { Conc } \\
(\dot{\%})\end{array}$} & \multicolumn{3}{|c|}{$\begin{array}{l}\text { Percent Disease Intensity } \\
\text { (PDI) }\end{array}$} & \multirow[t]{2}{*}{ Avg.PDI } & \multirow[t]{2}{*}{$\begin{array}{l}\text { Avg. } \\
\text { PDC }\end{array}$} \\
\hline & & & 45 DAT & 60 DAT & 75 DAT & & \\
\hline $\mathbf{T}_{1}$ & $\begin{array}{l}\text { Trichoderma } \\
\text { viride }\end{array}$ & $2 \%$ & 14.66 & 20.26 & 24.60 & 19.84 & 52.97 \\
\hline $\mathbf{T}_{2}$ & $\begin{array}{l}\text { Pseudomona } \\
\text { S fluorescens }\end{array}$ & $2 \%$ & 15.38 & 26.07 & 32.30 & 24.58 & 41.73 \\
\hline $\mathbf{T}_{3}$ & $\begin{array}{c}\text { Garlic bulb } \\
\text { extract }\end{array}$ & $5 \%$ & 16.74 & 27.07 & 35.35 & 26.38 & 37.47 \\
\hline $\mathbf{T}_{4}$ & $\begin{array}{l}\text { Datura leaf } \\
\text { extract }\end{array}$ & $5 \%$ & 26.87 & 28.54 & 38.14 & 31.18 & 26.09 \\
\hline $\mathbf{T}_{5}$ & Neem oil & $5 \%$ & 16.37 & 26.73 & 33.70 & 25.6 & 39.32 \\
\hline $\mathbf{T}_{6}$ & $\begin{array}{l}\text { Tulsi Leaves } \\
\text { extract }\end{array}$ & $5 \%$ & 25.14 & 30.14 & 37.49 & 30.92 & 26.71 \\
\hline $\mathbf{T}_{7}$ & $\begin{array}{l}\text { Eucalyptus } \\
\text { oil }\end{array}$ & $5 \%$ & 15.21 & 22.55 & 31.03 & 22.93 & 45.65 \\
\hline $\mathbf{T}_{\mathbf{0}}$ & Control & & 27.26 & 32.79 & 68.53 & 42.19 & 00.00 \\
\hline \multicolumn{3}{|c|}{ F test } & $\mathbf{S}$ & $\mathbf{S}$ & $\mathbf{S}$ & - & - \\
\hline \multicolumn{3}{|c|}{ S.E. \pm} & 1.01 & 1.15 & 1.35 & 2.02 & - \\
\hline \multicolumn{3}{|c|}{$\mathrm{CD}(\mathrm{P}=0.05)$} & 2.18 & 2.47 & 2.91 & 4.35 & - \\
\hline
\end{tabular}


Fig.1 Efficacy of bioagents on the radial growth of C.capsici by dual culture technique

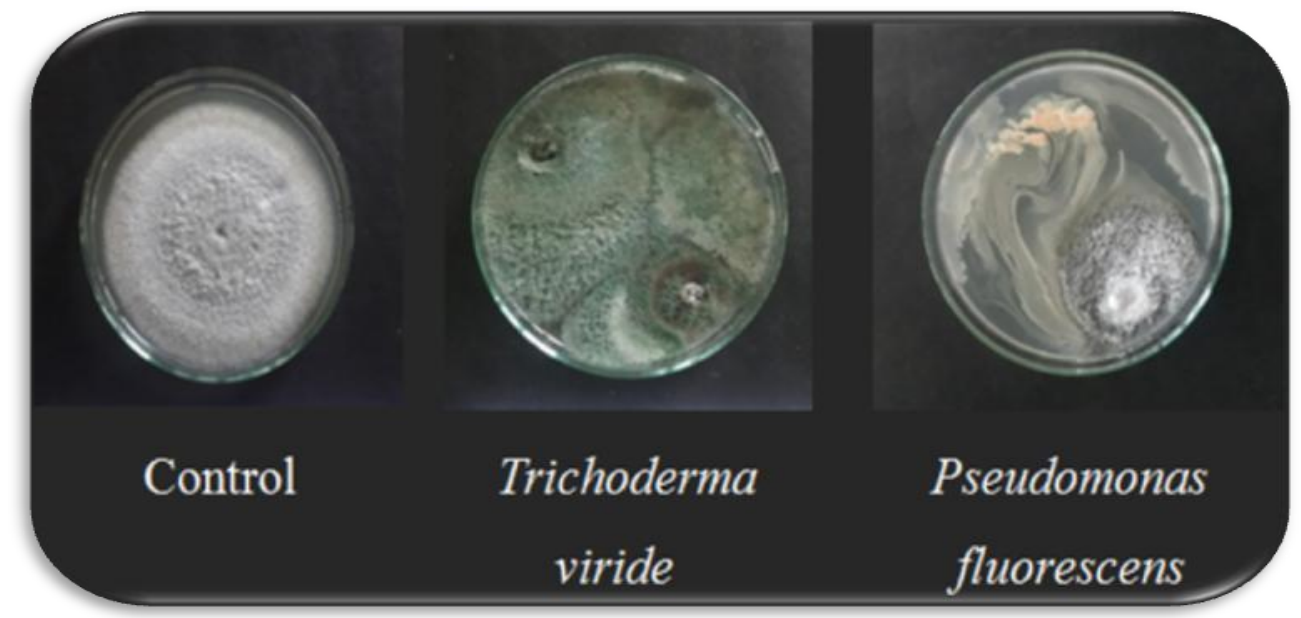

Fig.2 Efficacy of botanicals on the radial growth of $C$. capsici by poison food technique

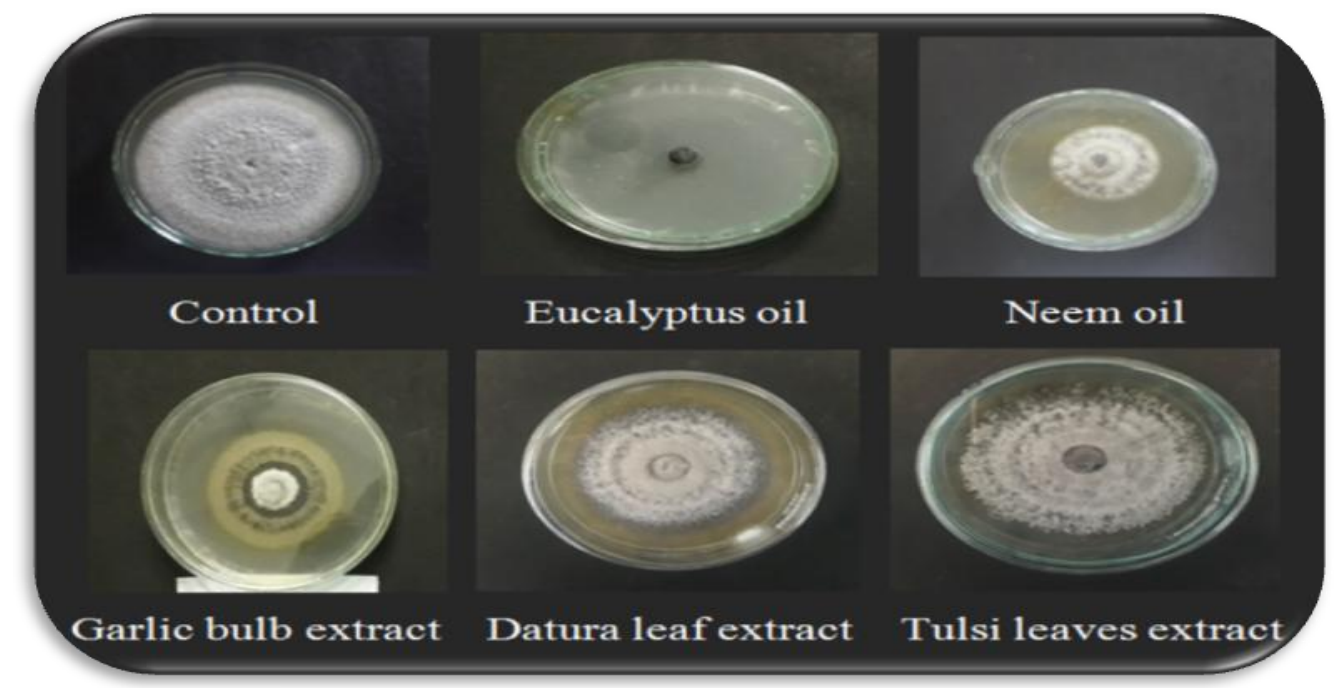

Fig.3 Effects of various treatments on anthracnose disease average percent intensity and reduction

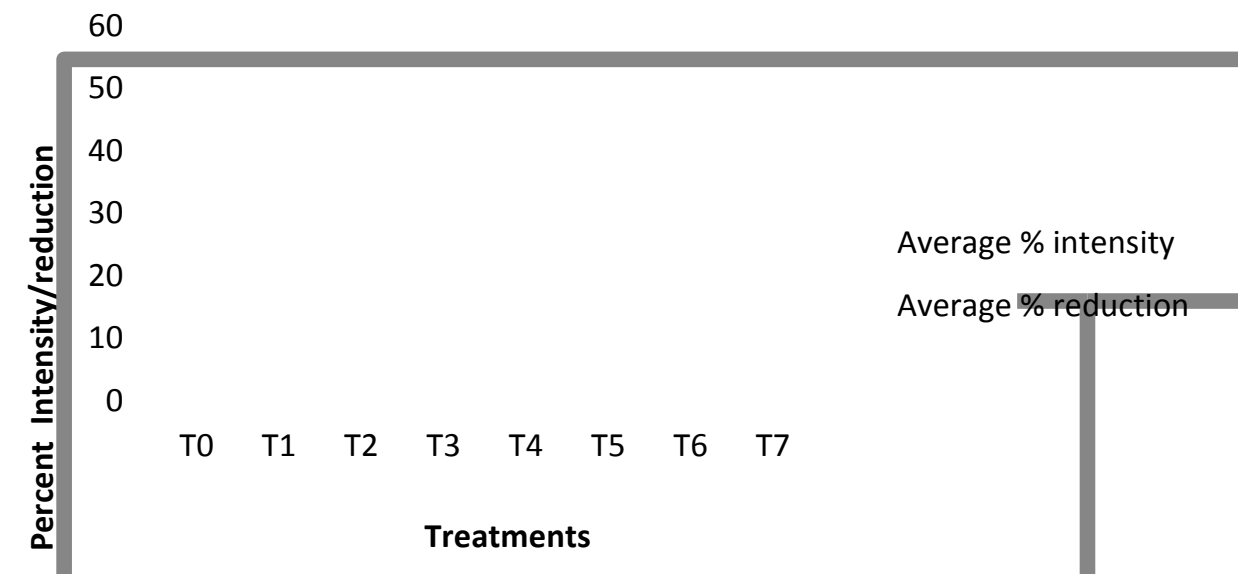


From present study, it was concluded that the severity of anthracnose of chilli disease can significantly be reduced by the use of bioagent Trichoderma viride and botanicals viz. Garlic bulb extract, Eucalyptus oil and Neem oil at least three times foliar spray after initiation of disease symptoms in order to have a higher profitable yield and higher economic return without health risk as well as environmental pollution. Whereas, in lab experiment Eucalyptus oil and Trichoderma viride, Pseudomonas fluorescens, Neem oil were found to be most effective. Recently there has been great interest in essential oils and biocontrol agents for controlling plant pathogens. The present study shows that botanical oils possess antifungal activity and can be exploited for effective management of plant diseases. Therefore, the farmers may be advised to take an integrated approach, which should be raised a profitable production without polluting the environment and adding toxins in the food chain.

\section{References}

Agrios, G. N. (2005). Plant Pathology, $5^{\text {th }}$ Ed. Academic Press San Diego pp 922

Bosland, P. W. and Votava, E. J. (2003). Peppers: Vegetable and Spice Capsicums. $\quad$ England: CAB International. (pp. 233).

Dennis, C. and Webster, J. (1971). Antagonistic properties of species group of Trichoderma and hyphal interactions. Transactions of the British Mycological Society, 57:363-369.

Hadden, J. F. and Black, L. L. (1987). Comparison of virulence of tomato and pepper isolates of Colletotrichum spp. Phytopathology 77: 641.

Hadden, J. F., Black, L. L., (1989). Anthracnose of Pepper caused by Colletotrichum spp. Proceedings of the International Symposium on Integrated Management Practices: Tomato and
Pepper Production in the Tropics. Asian Vegetable Research and Development Centre, Taiwan, (pp 189-199).

Jeyalakshmi, C., Durairaj, P., Seetharaman, K. and Sivaprakasham, K. (1998).Biocontrol of fruit rot and die back of chilli using antagonistic microorganisms. Indian Phytopathology. 51 (2): 180-183.

Kamble, H. N., Dhutraj, D.N. and Utpal, Dey. (2015). Field management of anthracnose of chilli (Capsicum annuиm) caused by Colletotrichum capsici. Indian Phytopathology. 68 (2): 179-185 (2015)

Mayee, C. D. and Datar, V. V. (1986). Diseases of groundnut in the topics. Rev. Trop. Plant Pathology.5: 85-118

Nene, Y. L. and Thapliyal, P. N. (1971). Fungicide in plant disease control. Oxford and IBH Publishing Compony Private Limited India.

Pardhi, S. and Raut, B. (2011). Efficacy of bioagents and botanicals against $C$. capsici causing fruit rot of chilli. Journal of Plant Disease and Science. 6 (2): 114-116.

Ramezani, H., Singh, H. P., Batis, D.R.O., Kohli, R.K. (2002). Antifungal activity of volatile oil of eucalayptus citriodora.Fitoterapia.2002; 73: 261-62.

Sahitya, L.U., Deepthi, S.R., Kasim, P.D., Suneetha P and Krishna, M.S. (2014). Anthracnose, a Prevalent Disease in Capsicum. Department of Biotechnology, KL University, India. Acharya N.G. Ranga University, Hyderabad. Research Journal of Pharmaceutical, Biological and Chemical Sciences 5 (3): 1583-1604.

Shinde, J. U. and Gawai, D. U. (2014). Efficacy of leaf extracts of some medicinal plants on growth of $C$. capsici. African Journal of Plant Science. 8 (7): 353-355.

Sydow, H. (1913). Beitrage Zur kenntnis der 
pilzflora des sudlichen Ostindiens I. Ann Mycologia, 11: 329-330.

Tiwari, P. K., Kasyap, A., Awadhioya, G. K. and Thrimurty, V. S. (2008). Efficacy of bioagents, neem based plant products and plant extracts against Colletotrichum capsici. Indian Journal of Plant Protection. 36 (1): 94-97.

\section{How to cite this article:}

Rohan D. Lokhande, Shashi Tiwari and Rupesh V. Patil. 2019. Eco-friendly Management of Anthracnose of Chilli (Capsicum annuum L.) caused by Colletotrichum capsici (Syd.) Butler and Bisby. Int.J.Curr.Microbiol.App.Sci. 8(02): 1045-1052. doi: https://doi.org/10.20546/ijcmas.2019.802.123 